\title{
Oviposition behavior of Helicoverpa armigera in soybean
}

\section{Comportamento de oviposição de Helicoverpa armigera em soja}

\author{
Renato Franco Oliveira de Moraes ${ }^{1 *}$ (1) (https://orcid.org/0000-0002-5199-6763) \\ Arlindo Leal Boiça Júnior ${ }^{1}$ (1) (https://orcid.org/0000-0003-1125-0251) \\ Wellington Ivo Eduardo ${ }^{1}$ (i) (https://orcid.org/0000-0002-6035-3284) \\ Zulene Antônio Ribeiro' (1) (https://orcid.org/0000-0002-3201-8956)
}

\begin{abstract}
The objective of this study was to evaluate the oviposition behavior of Helicoverpa armigera confined in different adult pair density and growth stages of soybean plants, and the resistance of soybean genotypes to $H$. armigera in the category nonpreference for oviposition. The oviposition behavior of $H$. armigera was assessed using one, two, and four adult pairs per soybean plant of the cultivar BR-16 at the growth stages: vegetative V8 (eighth unrolled trifoliate leaf), reproductive R2 (full bloom) and reproductive R5.2 (beginning seed). The nonpreference for oviposition was evaluated using eight soybean genotypes and an oviposition preference index was calculated. The number of trichomes in leaflets was quantified for being correlated to $H$. armigera oviposition. One adult pair and soybean plants stage at pod-set affected and showed the best results oviposition preference on soybean plants. The genotypes M8230-RR and W711-RR presented resistance characteristics, and PI-227687 was preferred for oviposition. The trichome density positively affects the female oviposition behavior.
\end{abstract}

KEYWORDS: host plant selection; Glycine $\max$ (L.); nonpreference for oviposition; plant resistance to insects.
RESUMO: O objetivo deste trabalho foi avaliar o comportamento de oviposiçáo de Helicoverpa armigera confinadas em diferentes densidades de casais e estádios fenológicos de plantas de soja, e a resistência de genótipos de soja na categoria não preferência para oviposição para $H$. armigera. Para o comportamento de oviposição de H. armigera, foram avaliadas as densidades de um, dois e quatro casais por planta, e os estádios fenológicos vegetativo, de florescimento e reprodutivo de plantas de soja do cultivar BR 16. Para o teste de náo preferência para oviposiçáa, oito genótipos de soja foram utilizados e um índice de preferência para oviposição foi calculado. A densidade de tricomas nos folíolos foi quantificada para ser correlacionada com a oviposição de $H$. armigera. A densidade de um casal e plantas de soja em estádio reprodutivo proporcionaram os melhores resultados quanto à preferência para oviposição de $H$. armigera em soja. Os genótipos M8230 RR e W711 RR apresentaram características de resistência, enquanto o PI 227687 foi o mais preferido para oviposição. A quantidade de tricomas influenciou positivamente no comportamento de oviposiçáo das fêmeas.

PALAVRAS-CHAVE: seleção hospedeira; Glycine max (L.); não preferência para oviposição; resistência de plantas a insetos. 


\section{INTRODUCTION}

Host plant selection is one of the main functions of females of many species of phytophagous insects, mainly lepidopterous, which usually do not migrate to long distances during their immature stage (SRINIVASAN et al., 2006), causing dependence on the choice of hosts by their progenitors. Host plant selection is constantly affected by specific stimuli, mainly by secondary metabolism compounds of plants and plant morphological characteristics (AFZAL et al., 2012), which are identified by specialized chemoreceptors in the insects.

BOIÇA JÚNIOR et al. (2015) reported that the insect oviposition behavior may be affected by age and structure of the plant and the age and population density of the insects. According to LARA (1991), some changes in the host plant negatively affect the insect oviposition behavior during the host selection, denoting the resistance of these plants in the category nonpreference or antixenosis. Morphological attributes such as trichomes, epicuticular wax, and hardness of the plant structure are among the genetic characteristics of soybean plants that can affect the female host selection for oviposition (WAR et al., 2012). Trichomes are morphological adaptations of plants that have several functions and may affect the oviposition of insects due to the release of substances that repel them or hinder their locomotion and oviposition on the leaf surface (RODRIGUES et al., 2012).

Genetic resistance, or nonpreference of soybean genotypes to insect-pests had already been found for other Lepidoptera species in Brazil, including Spodoptera eridania (Cramer, 1872) (Lepidoptera: Noctuidae) (SOUZA et al., 2012) and Anticarsia gemmatalis (Hübner, 1818) (Lepidoptera: Erebidae) (FRANCO et al., 2014). However, researches on genetic resistance of soybean to Helicoverpa armigera (Hübner, 1805) (Lepidoptera: Noctuidae) have been conducted only in other countries, using different conditions and genotypes (SOLEIMANNEJAD et al., 2010; NASERI et al., 2010).

Soybean has stood out among Brazilian agricultural crops mainly due to the recurrent records in production of this oilseed. The Brazilian grain production has reached 120,9 million $\mathrm{Mg}$ in a planted area of 36,9 million hectares in the 2017/18 agricultural year $(\mathrm{CONAB}, 2020)$. The $H$. armigera insects were first reported in Brazil in 2013; this species showed to be an important polyphagous species that stood out by hosting several crops of economic importance, including soybean (CZEPAK et al., 2013). Thus, researches on resistance of soybean genotypes to $H$. armigera in Brazil is important for its inclusion in integrated pest management systems. In this context, the objective of this study was to evaluate the oviposition behavior of $H$. armigera confined in different adult pair density and growth stages of soybean plants, and the resistance of soybean genotypes to $H$. armigera in the category nonpreference for oviposition.

\section{MATERIAL AND METHODS}

The tests were conducted in laboratory and greenhouse conditions from October to November 2015. The insects used in the tests were rearing in an artificial diet, as described by GREENE et al. (1976). Five-day-old adults of H. armigera was used, this period of five days was determined through observations of peak oviposition activity for adults in the laboratory colony. Soybean genotypes seeds used in the tests were sown in 5-liter pots containing soil, tanned cattle manure, and sand at the ratio of 3:1:1. Pots were placed in a greenhouse and watered as needed. No other cultural practices were carried out to avoid the detection of false resistances.

\section{Oviposition behavior assay}

The soybean cultivar BR 16, described by PIUBELLI et al. (2005) as susceptible to A. gemmatalis (Hübner, 1818) (Lepidoptera: Erebidae), which is an insect-pest also found in soybean crops, was used as a standard susceptible cultivar due to absence of studies on soybean genotypes susceptible to $H$. armigera in Brazil. The plant phenological stages used was determined according to the methodology described by FEHR; CAVINESS (1977).

The assay performed to assess the oviposition behavior of $H$. armigera in different adult pair densities was conducted in a completely randomized design, with 10 replications per treatment (one, two, and four adult pairs per plant). Soybean plants at the vegetative phenological stage (V8) were used. Acrylic cylindrical cages with $45 \mathrm{~cm}$ diameter and $80 \mathrm{~cm}$ height were covered with expanded polystyrene and placed on the 5-liter pots containing one soybean plant (replicate) and $H$. armigera adults were then released, using the respective densities.

The growth plant stage of the soybean plant preferred for oviposition by $H$. armigera was determined in free-choice and no-choice tests, using the number of adult pairs determined in a previous test (see results) with the following treatments: plants at vegetative (V8 - eighth unrolled trifoliate leaf), reproductive (R2 - full bloom), and reproductive (R5.2 beginning seed) stages, with 10 replications per treatment. The free-choice test was conducted using soybean plants arranged in acrylic cylindrical cages with $80 \mathrm{~cm}$ diameter and $70 \mathrm{~cm}$ height covered with white expanded polystyrene and placed on the 5-liter pots containing the soybean plants. The no-choice test was conducted using cages as previously described for the assay for density of adult pairs, where adults were released into plants of the same stage of development used in the free choose test. The number of eggs per plant after $24 \mathrm{~h}$ from the beginning of the assays were evaluated in both experiments (density of pairs per plant and plant phenological stage). 


\section{Oviposition preference assay of $H$. armigera on soybean genotypes}

Oviposition preference assay of $H$. armigera on soybean genotypes was conducted using plants at the R2 stage, with five replications per treatment in free-choice tests under randomized block design. Eight soybean genotypes were used: PI 227682, PI 227687, CD 208, IAC 100, BRS Valiosa RR, M7908 RR, M8230 RR, and W711 RR. The plants were placed equidistantly from the center of steel cages $(100 \mathrm{~cm}$ height, $150 \mathrm{~cm}$ width, and $150 \mathrm{~cm}$ depth) covered with a voile cloth, where one adult pair of 5-day-old $H$. armigera was released per plant. The number of eggs per plant was evaluated after $24 \mathrm{~h}$.

The number of eggs recorded per plant was used to calculate the oviposition preference index (OPI) through the adaptation of the formula described by FENEMORE (1980) (Eq. 1):

$$
\mathrm{OPI}=[(T-M) /(T+M)] \times 100
$$

Where $T$ is the number of eggs in the test treatment, and $M$ is the mean number of eggs in the tested genotypes. The OPI varies from +100 (highly stimulant) to -100 (high deterrent). The OPI was classified considering the mean standard error of the assay to differentiate the genotypes. The original formula compares a test genotype to a standard genotype previously defined as susceptible; however, considering that information on susceptible genotypes are scarce in the literature for this species, the mean number of eggs was used instead of the standard susceptible genotype.

The mean number of trichomes was quantified following methodology described by LIMA; LARA (2004). A stereoscopic microscope $(40 \times)$ was used to count the number of trichomes in two circular areas of $3.14 \mathrm{~mm}^{2}$, one at left and one at the right from the main rib, centered between the main rib and the leaflet margin, in abaxial and adaxial parts of two totally expanded leaflets per plant, in five different plants, representing five replications consisted of two leaflets. The number of trichomes in the circular areas of $3.14 \mathrm{~mm}^{2}$ was extrapolated to number of trichomes per square centimeter.

\section{Statistical analysis}

The data were subjected to normality (Kolmogorov-Smirnov) and homoscedasticity (Bartlett) tests, using the Assistat program (SILVA; AZEVEDO, 2016). When the data presented no normal distribution or homogeneity of variances, they were transformed according to Box-Cox test, using the SAS 9.4 program (SAS, 2011) and then subjected to analysis of variance by the F-test. When the means were significant by the F-test, they were compared by the Tukey's test at 5\% probability, using the AgroEstat program (BARBOSA; MALDONADO JUNIOR, 2015).

\section{RESULTS AND DISCUSSION}

The mean number of eggs was significantly higher in the density of four adult pairs of $H$. armigera per plant; however, the number of eggs per female did not increase when a higher number of pairs was confined per plant (Fig. 1). Thus, considering that the mean number of eggs per female was similar in all densities used, the use of many pairs of insects was not needed, since the number of eggs is proportional to the number of adult pairs used. Moreover, the effect of the plant was eliminated in this test because of the use of plants in the same nutritional condition and phenological stage. Thus, one adult pair per plant can be used as the best density of $H$. armigera, since it showed to be enough and interesting to conduct resistance assays for soybean plants. (a)

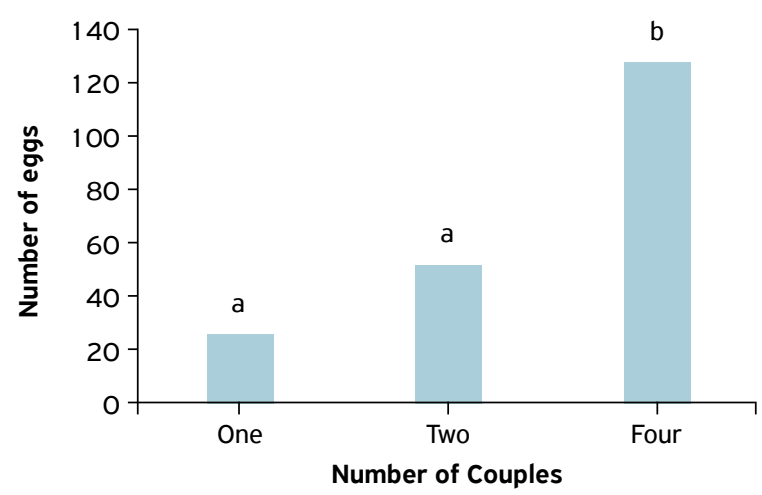

(b)

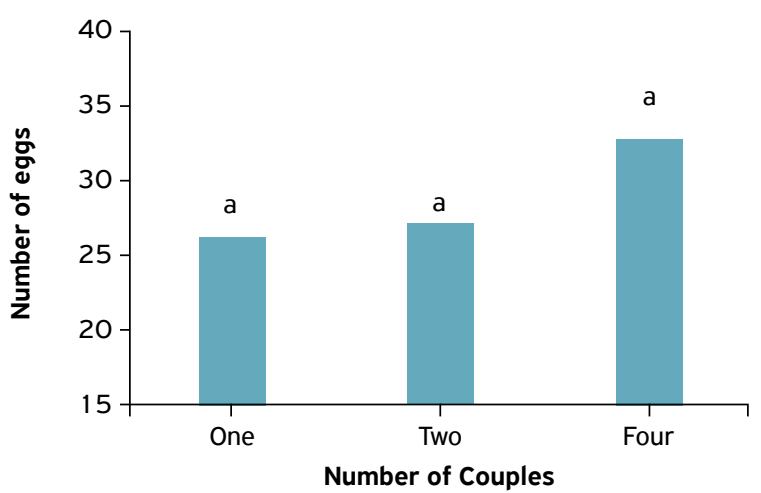

Temperature: $25 \pm 1{ }^{\circ} \mathrm{C} ; \mathrm{RH}: 70 \pm 10 \%$; photophase: $12 \mathrm{~h}$. Columns followed by different letters in each column are significantly different by the Tukey's test $(p<0.05)$. For analysis, the data were transformed into $(X+1)^{1 / 2}$. Number of eggs: $F=16.49^{* *}, p=<0.0001$, Eggs per female: $F=0.54 n s, p=0.5883$.

Figure 1. Number of eggs (a) and eggs per female (b) of $H$. armigera (mean $\pm \mathrm{SE}$ ) on the genotype BR 16 genotype under different adult pair density: one, two, and four. Jaboticabal, SP, 2015. 
According to BOIÇA JÚNIOR et al. (2010), studies on insect density for resistance tests are important, since a genotype can show resistance to a pest up to a specific pest density, showing similar damages to those found in susceptible genotypes subjected to higher pest densities. Contrastingly, low pest populations can cause lower damages to crops, leading to detection of false understandings and false resistances, or even hindering the differentiation of genotypes regarding resistance levels (LARA, 1991).

Helicoverpa armigera showed preference for oviposition on soybean plants at reproductive stages in the free-choice test, differently the number of eggs on soybean plants were similar in all plant growth stages in the no-choice test (Fig. 2). Thus, the $H$. armigera oviposition behavior is affected by the growth stages of soybean plants, since females preferred to lay their eggs on plants at the pod-set stages (R2 and R5.2) when they have a choice.

This result confirms those of JALLOW et al. (2001), who found that maize, tomato, okra, eggplant, and chili plants at the reproductive stage were the most preferred for oviposition by $H$. armigera. Therefore, plants at the pod-set stage could be used for oviposition tests, since $H$. armigera females had already expressed preference for these plants. The pod-set stage used R2 (full bloom) and R5.2 (beginning seed) showed no significant differences between them. The use of plants at later growth stages may make studies of resistance of soybean to this insect-pest longer, which is not interesting. The $H$. armigera females selected soybean plants that presented desirable conditions and characteristics for their offspring, which may be related to the food nutritional aspects or quantity, plant genetics, presence of trichomes, and secondary chemical compounds.

The number of eggs on the genotypes M8230 RR, W711 RR, and CD 208 was significantly lower compared to the genotype PI 227687. The number of eggs found for PI 227687 was 8.1, 7.5 and 4.2 times higher than the mean number of eggs of M8230 RR, W711 RR and CD 208 respectively (Table 1 ). (a)

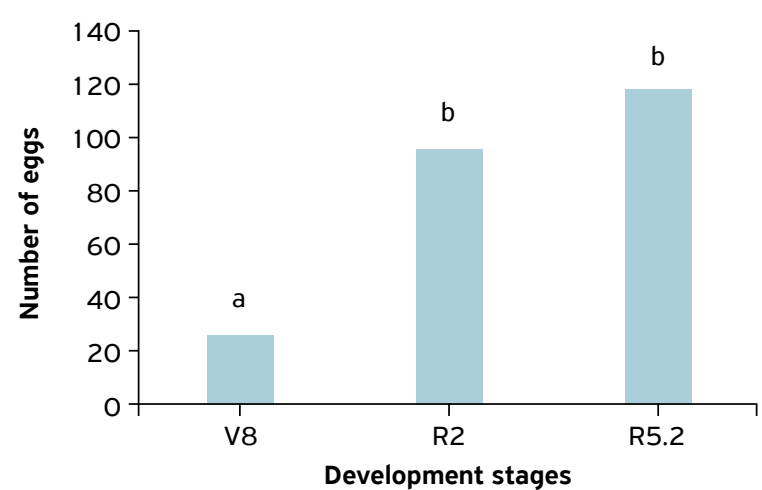

(b)

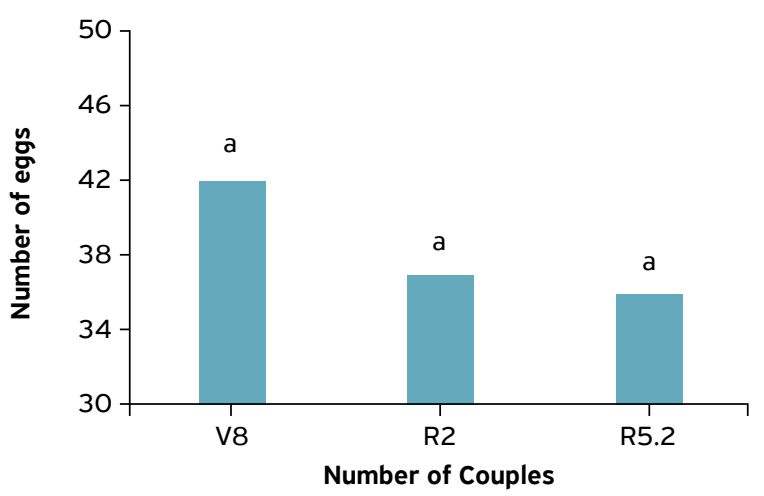

Temperature: $25 \pm 1{ }^{\circ} \mathrm{C}$; RH: $70 \pm 10 \%$; photophase: $12 \mathrm{~h}$. Columns followed by different letters in each column are significantly different by Tukey's test $(p<0.05)$. ${ }^{1}$ For analysis, the data were transformed into $(X+1)^{1 / 2}$. Free choice: $F=7.10 * *, p=0,0032 ; n o-c h o i c e: F=0.20$ ns, $p=0.8460$.

Figure 2. Number of eggs (mean $\pm \mathrm{SE}$ ) of $H$. armigera per plant of the genotype BR 16 under development stages: vegetative (V8), flowering (R2) and pod-set (R5.2) on free choice (A) and no-choice (B) tests. Jaboticabal, SP, 2015.

Table 1. Number of eggs (mean \pm SE) of $H$. armigera in soybean genotypes and trichome density per $\mathrm{cm}^{2}$. Jaboticabal, SP, 2015

\begin{tabular}{|c|c|c|}
\hline Genotypes & Number of eggs ${ }^{1}$ & Trichome density \\
\hline M8230 RR & $30.6 \pm 9.6 a$ & $3809.0 \pm 543.9 d$ \\
\hline CD 208 & $57.6 \pm 31.7 a$ & $1274.0 \pm 56.9 a$ \\
\hline IAC 100 & $63.4 \pm 32.7 a b$ & $2401.4 \pm 172.5 \mathrm{bcd}$ \\
\hline PI 227687 & $246.8 \pm 101.8 b$ & $6471.4 \pm 1156.4 \mathrm{e}$ \\
\hline W711 RR & $32.6 \pm 11.9 a$ & $2108.2 \pm 368.1 \mathrm{bcd}$ \\
\hline BRS Valiosa RR & $118.6 \pm 18.4 a b$ & $1668.6 \pm 180.8 a b$ \\
\hline PI 227682 & $90.4 \pm 30.5 a b$ & $2783.2 \pm 273.3 \mathrm{~cd}$ \\
\hline M7908 RR & $123.2 \pm 16.5 a b$ & $1891.6 \pm 64.1 \mathrm{abc}$ \\
\hline$F$ & $3.87^{* *}$ & $25.56^{* *}$ \\
\hline$P$ & 0.0039 & $<0, .001$ \\
\hline
\end{tabular}

Temperature: $25 \pm 1{ }^{\circ} \mathrm{C}$; RH: $70 \pm 10 \%$; photophase: $12 \mathrm{~h}$. Means followed by different letters in each column are significantly different by Tukey's test $(\mathrm{p}<0.05)$. ${ }^{1}$ For analysis, the data were transformed into $(\mathrm{X})^{\wedge} 0,25 .{ }^{2}$ For analysis, the data were transformed into Log $(X) .{ }^{* *}$ significant at $1 \%$ probability. 
The results of preference for oviposition of $H$. armigera in the free-choice test showed that the soybean genotypes M8230 RR, W711 RR, and CD 208 present characteristics that differentiated them from the other genotypes in relation to preference for oviposition. According to PIUBELLI et al. (2005) and WAR et al. (2012), the insect preference for oviposition can be related to the presence of chemical compounds or morphological characteristics of the plant, which have stimulant or suppressive effect on oviposition.

PI 227687 presented larger mean number of trichome differing significantly from W711 RR, IAC 100, PI 227682 and M8230 RR, which differed from the genotype that presented the smallest mean number (CD 208) (Table 1). Thus, the oviposition of $H$. armigera was, in general, affected by this morphological characteristic in soybean plants, with lower oviposition on genotypes with lower number of trichomes (M8230 RR, W711 RR, and CD 208) and higher oviposition on genotypes with higher trichome number (PI 227687).

Therefore, a small number of trichomes is not a favorable morphological attribute of soybean plants to $H$. armigera oviposition, since genotypes with many trichomes were the most preferred by females. The results showed that $H$. armigera females prefer to oviposit on soybean plants with large number of trichomes; similar results were reported by JALLOW et al. (1999), who found that $H$. armigera females prefer to oviposit on parts of cotton plants containing larger number of trichomes. Contrastingly, GIRIJA et al. (2008) found that the presence of trichomes negatively affected $H$. armigera oviposition on chickpea plants. However, KUMARI et al. (2006) found that the larger the number of trichomes, the lower the damages caused by $H$. armigera larvae in pigeon pea plants. WAR et al. (2012) pointed out that trichomes in plants can differently affect insects, positively or negatively. Studies on effects of trichomes on the oviposition behavior of $H$. armigera for soybean crops are still scarce in the literature, thus, further studies are required to understand this correlation, mainly regarding the importance of type, number, and size of trichomes for the oviposition of $H$. armigera.

The OPI (Fig. 3) of the soybean genotypes M8230 RR, W711 RR, and CD 208 were deterrents. Different from previous genotypes, IAC 100, PI 227682, BRS Valiosa RR, and M7908 RR were neutral according to OPI. Contrastingly, PI 227687 showed stimulant OPI, which was probably due to the presence of large number of trichomes.

The results of the present study denote that the adult pair density of $H$. armigera and the growth stages of soybean plants may affect the oviposition behavior of $H$. armigera. In addition, some soybean genotypes presented resistance characteristics in the category nonpreference for oviposition, and this resistance was probably due to a morphological characteristic: number of trichomes.

\section{CONCLUSIONS}

The adult pair density of $H$. armigera and the growth stages of soybean plants affect the $H$. armigera oviposition behavior, since the use of one pair of $H$. armigera and soybean plants at the R2 reproductive stage showed the best results on preference for oviposition on soybean plants.

The genotypes M8230-RR and W711-RR present characteristics of resistance to $H$. armigera, and PI-227687 is preferred soybean genotype for oviposition.

Soybean genotypes with higher trichome density are preferred for $H$. armigera oviposition.

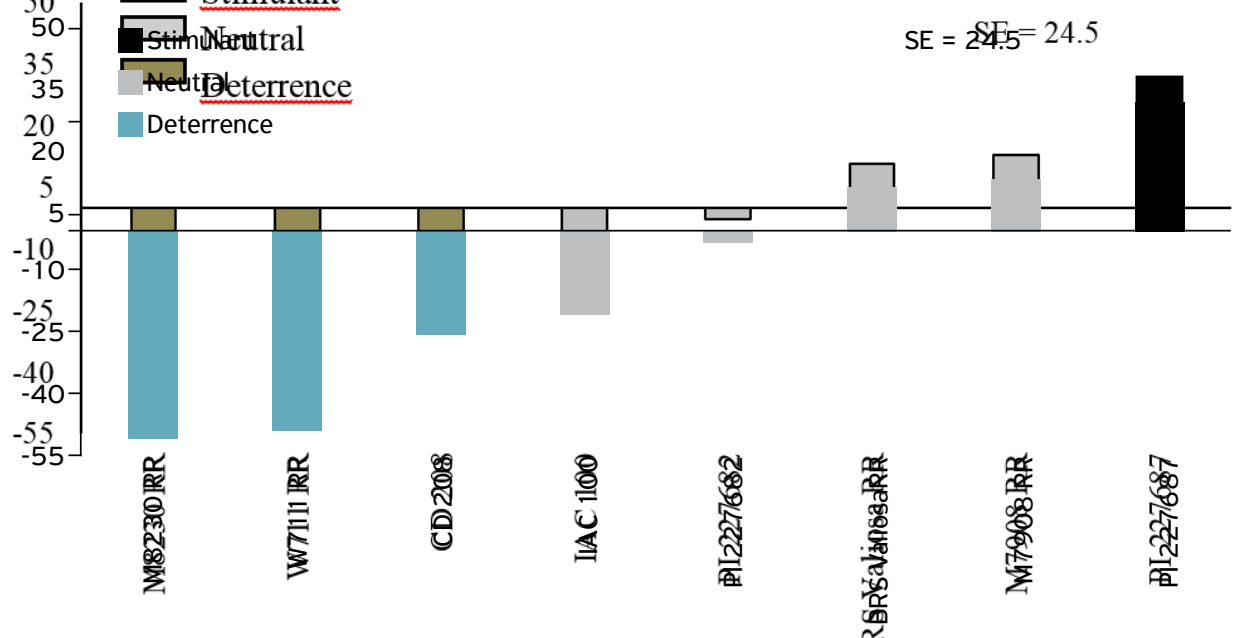

$\mathrm{SE}=$ standard error.

Figure 3. Oviposition preference index (OPI) and soybean genotype classification regarding the oviposition of $H$. armigera in freechoice test. Jaboticabal, SP, 2015. 
ACKNOWLED GEMENTS: Not applicable.

FUNDING: This work did not receive any specific grant from funding agencies in the public, commercial, or not-for-profit sectors.

CONFLICTS OF INTEREST: The authors certify that they have no commercial or associative interest that represents a conflict of interest in connection with the manuscript.

ETHICAL APPROVAL: Not applicable.

AVAILABILITY OF DATA AND MATERIAL: The datasets generated and/or analyzed during the current study are available in the Repositório Institucional UNESP. http://hdl.handle.net/1 1449/148891

AUTHORS' CONTRIBUTIONS: Conceptualization: Moraes, R.F.O.; Boiça Junior, A.L.: Eduardo, W.I.; Ribeiro, Z.A. Data curation: Moraes, R.F.O.; Boiça Junior, A.L.: Eduardo, W.I.; Ribeiro, Z.A. Formal analysis: Moraes, R.F.O.; Boiça Junior, A.L.: Eduardo, W.I.; Ribeiro, Z.A. Investigation: Moraes, R.F.O.; Boiça Junior, A.L.: Eduardo, W.I.; Ribeiro, Z.A. Methodology: Moraes, R.F.O.; Boiça Junior, A.L.: Eduardo, W.I.; Ribeiro, Z.A. Project administration: Moraes, R.F.O.; Boiça Junior, A.L.: Eduardo, W.I.; Ribeiro, Z.A. Resources: Moraes, R.F.O.; Boiça Junior, A.L.: Eduardo, W.I.; Ribeiro, Z.A. Supervision: Moraes, R.F.O.; Boiça Junior, A.L.: Eduardo, W.I.; Ribeiro, Z.A. Validation: Moraes, R.F.O.; Boiça Junior, A.L.: Eduardo, W.I.; Ribeiro, Z.A. Visualization: Moraes, R.F.O.; Boiça Junior, A.L.: Eduardo, W.I.; Ribeiro, Z.A. Writing - original draft: Moraes, R.F.O.; Boiça Junior, A.L.: Eduardo, W.I.; Ribeiro, Z.A. Writing - review \& editing: Moraes, R.F.O.; Boiça Junior, A.L.: Eduardo, W.I.; Ribeiro, Z.A.

\section{REFERENCES}

AFZAL, M.; ASHFAQ, M.; BASHIR, M.H. Oviposition responses of Helicoverpa armigera towards the morphological plant characters of some genotypes of cotton. Pakistan Journal of Zoology, Burnley, v.44, n.4, p.1091-1097, 2012. Available from: http://zsp. com.pk/pdf44/1091-1097\%20_28_\%20PJZ-310-10\%20 oviposition\%20responses\%20of\%2Ohelicoverpa.pdf. Access on: 13 Jun. 2015

BARBOSA, J.C.; MALDONADO JÚNIOR, W. Experimentação agronômica \& AgroEstat: sistema para análises estatísticas de ensaios agronômicos. Jaboticabal: Multipress, 2015. 396p.

BOIÇA JÚNIOR, A.L.; CHAGAS FILHO, N.R.; SOUZA, J.R. Não-preferência para oviposição de traça-das-crucíferas em genótipos de couve-flor. Revista Caatinga, Mossoró, v.23, n.1, p.28-33, 2010 .

BOIÇA JÚNIOR, A.L.; SOUZA, B.H.S.; COSTA, E.N.; RIBEIRO, Z.A.; STOUT, M.J. Factors influencing expression of antixenosis in soybean to Anticarsia gemmatalis and Spodoptera frugiperda (Lepidoptera: Noctuidae). Journal of Economic Entomology, College Station, v.108, n.1, p.317-325, 2015. https://doi. org/10.1093/jee/tou007

COMPANHIA NACIONAL DE ABASTECIMENTO (CONAB). Acompanhamento de safra brasileira: grãos. v.7 - Safra 2019/20, n. 11 - Décimo primeiro levantamento. Brasília: Companhia Nacional de Abastecimento, 2020. 33p. Available from: https://www. conab.gov.br/info-agro/safras/graos/boletim-da-safra-de-graos. Access on: 25 Jul. 2020.
CZEPAK, C.; ALBERNAZ, K.C.; VIVAN, L.M.; GUIMARÃES, H.O.; CARVALHAIS, T. Primeiro registro de ocorrência de Helicoverpa armigera (Hübner) (Lepidoptera: Noctuidae) no Brasil. Pesquisa Agropecuária Tropical, Goiânia, v.43, n.1, p.110-113, 2013. https://doi.org/10.1590/S1983-40632013000100015

FEHR, W.R.; CAVINESS, C.E. (1977). Stages of soybean development. Ames: lowa State University of Science and Technology. Special Report 80. Available from: https://lib.dr.iastate.edu/cgi/ viewcontent.cgi?article $=1076 \&$ context $=$ specialreports. Access on: 3 Apr. 2015.

FENEMORE, P.G. Oviposition of potato tuber moth, Phthorimaed operculella Zell. (Lepidoptera: Gelechiidae); identification of host-plant factors influencing oviposition response. New Zealand Journal of Zoology, New Zealand, v.7, n.3, p.435-439, 1980. https://doi.org/10.1080/03014223.1980.10423798

FRANCO, A.A.; QUEIROZ, M.S.; PERES, A.R.; ROSA, M.E.; CAMPOS, A.R.; CAMPOS, Z.R. Preferência alimentar de Anticarsia gemmatalis Hübner (Lepidoptera: Noctuidae) por cultivares de soja. Científica, Jaboticabal, v.42, n.1, p.32-38, 2014. https:// doi.org/10.15361/1984-5529.2014v42n1p32-38

GIRIJA, S.P.M.; PATIL, S.A.; GOWDA, C.L.L.; SHARMA, H.C. Biophysical and biochemical basis of host plant resistance to pod borer (Helicoverpa armigera Hubner) in chickpea (Cicer arietinum L.). The Indian Journal of Genetics and Plant Breeding, New Delhi, v.68, n.3, p.320-323, 2008. Available from: https:// www.indianjournals.com/ijor .aspx?target $=$ ijor:ijgpb\&volume $=6$ $8 \&$ issue $=3 \&$ article $=016$. Access on: 17 Aug. 2017 . 
GREENE, G.L.; LEPLA, N.C.; DICKERSON, W.A. Velvetbean caterpillar: A rearing procedure and artificial medium. Journal of Economic Entomology, College Station, v.69, n.4, p.487-488, 1976. https://doi.org/10.1093/jee/69.4.487

JALLOW, M.F.A., ZALUCKI, M.P.; FITT, G.P. Role of chemical cues from cotton in mediating host selection and oviposition behaviour in Helicoverpa armigera (Hübner) (Lepidoptera: Noctuidae). Australian Journal of Entomology, Adelaide, v.38, n.4, p.359-366, 1999. https://doi.org/10.1046/j.1440-6055.1999.00131.x

JALLOW, M.F.A.; MATSUMURA, M.; SUZUKI, Y. Oviposition preference and reproductive performance of Japanese Helicoverpa armigera (Hübner) (Lepidoptera: Noctuidae). Applied Entomology and Zoology, Tokyo, v.36, n.4, p.419-426, 2001. https://doi. org/10.1303/aez.2001.419

KUMARI, D.A.; REDDY, D.J.; SHARMA, H.C. Antixenosis mechanism of resistance in pigeonpea to the pod borer, Helicoverpa armigera. Journal of Applied Entomology, Goettingen, v. 130, n. 1, p.10-14, 2006. https://doi.org/10.1111/j.1439-0418.2005.01024.x

LARA, F.M. Princípios de resistência de plantas a insetos. São Paulo: Ícone, 1991.336p.

LIMA, A.C.S.; LARA, F.M. Resistência de genótipos de soja à mosca branca Bemisia tabaci (Genn.) Biótipo B (Hemiptera: Aleyrodidae). Neotropical Entomology, Londrina, v.33, n.1, p.71-75, 2004. https://doi.org/10.1590/ S1519-566X2004000100013

NASERI, B.; FATHIPOUR, Y;; MOHARRAMIPOUR, S.; HOSSEININAVEH, V. Nutritional indices of the cotton bollworm, Helicoverpa armigera, on 13 soybean varieties. Journal of Insect Science, Negev, v. 10 , n.151, p.1-14, 2010. https://doi.org/10.1673/031.010.1411

PIUBELLI, G.C.; HOFFMANN-CAMPO, C.B.; MOSCARDI, F.; MIYAKUBO, S.H.; OLIVEIRA, M.C.N. Are chemical compounds important for soybean resistance to Anticarsia gemmatalis? Journal of Chemical Ecology, State College, v.31, n.7, p.1509-1525, 2005. https://doi.org/10.1007/s10886-005-5794-z
RODRIGUES, D.M.; SOUZA, C.R.; AGUIAR, R.W.S.; MELO, A.V.; SILVA, J.C.; OOTANI, M.A.; CRUZ, W.P. Tricomas conferem resistência contra herbivoria de Cerotoma arcuata em cultivares de soja. Agroecossistemas, Pará, v.4, n.2, p.33-39, 2012. https://doi. org/10.18542/ragros.v4i2.1211

SILVA, F.A.S.; AZEVEDO, C.A.V. The Assistat Software Version 7.7 and its use in the analysis of experimental data. African Journal of Agricultural Research, Lagos, v.39, n. 1 1, p.3733-3740, 2016. https://doi.org/10.5897/AJAR2016.11522

SOLEIMANNEJAD, S.; FATHIPOUR, Y.; MOHARRAMIPOUR, S.; ZALUCKI, M.P. Evaluation of potential resistance in seeds of different soybean cultivars to Helicoverpa armigera (Lepidoptera: Noctuidae) using demographic parameters and nutritional indices. Journal of Economic Entomology, College Station, v.103, n.4, p.1420-1430, 2010. https://doi.org/10.1603/EC10022

SOUZA, B.H.S.; BOIÇA JÚNIOR, A.L.; JANINI, J.C.; SILVA, A.G.; RODRIGUES, N.E.L. Feeding of Spodoptera eridania (Lepidoptera: Noctuidae) on soybean genotypes. Revista Colombiana de Entomologia, Bogotá, v.38, n.2, p.215-223, 2012. Available from: http://www.scielo.org.co/scielo.php?script=sci_arttext\&pi $d=$ SO $120-04882012000200009$. Access on: 17 Aug. 2017.

SRINIVASAN, R.; UTHAMASAMY, S.; TALEKAR, N.S. Characterization of oviposition attractants of Helicoverpa armigera in two solanaceous plants, Solanum viarum and Lycopersicon esculentum. Current Science, Bengaluru, v.90, n.6, p.846-850, 2006. Available from: https://www.jstor.org/stable/24089200?seq=1 \#metadata_ info_tab_contents. Access on: 17 Aug. 2017.

STATISTICAL ANALYSIS SYSTEM (SAS). SAS/STAT user software: changes and 14 enhancements through release. Version 9.3. Cary: SAS Institute, 2011. Available from: https://support.sas.com/ rnd/app/stat/9.3/dastat930.html. Access on: 16 Jul. 2017.

WAR, A.R.; PAULRAJ, M.G.; AHMAD, T.; BUHROO, A.A., HUSSAIN, B.; IGNACIMUTHU, S.; SHARMA, H.C. Mechanisms of plant defense against insect herbivores. Plant Signaling \& Behavior, Austin, v.7, n.10, p.1306-1320, 2012. https://doi.org/10.4161/psb.21663 